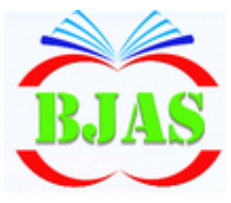

Available online at: http//bjas.bajas.edu.iq

College of Agriculture, University of Basrah

DOi:10.21276/basjas

ISSN $1814-5868$

Basrah J. Agric. Sci., 32(Spec Issue): 163-169, 2019

\section{Basrah}

Journal of

Agricultural

Sciences

E-ISSN: 2520-0860

\title{
Effect of the Bio-stimulator Amalgerol in some Growth and Yield Properties of Two Sweet Pepper (Capsicum annuum L.) Varieties
}

\author{
Abdul Basset M. Al-Mahdi, Nawal M. Al-Bayaty* \& Abbas K. Abaid \\ Department of Horticulture and Landscape Design, College of Agriculture, \\ University of Basrah, Basrah, Iraq \\ *Corresponding author e-mail: lehab007@yahoo.com \\ Received 20 March 2019; Accepted 13 July 2019; Available online 18 September 2019
}

\begin{abstract}
The field experiment was conducted during the agricultural season 2016-201 in one of the greenhouses belonging to the Directorate of Agriculture of Basrah in Khr Al-Zubair, in order to study the effect of the bio-stimulator Amalgerol in some grow 1 characteristics of two types of sweet pepper (Capsicum annuum L.). The trial included 1 treatments involving two types of sweet peppers: KAMAR, RIDA F1 and thr concentrations of both Amalgerol (0,2.5 and 5) $\mathrm{ml}^{-1}{ }^{-1}$ and the appetizer $(0,1$ and 1.5) $\mathrm{ml}$ 1. The factorial experiment was implemented with Split Plot Design by Randomize Complete Block Design (RCBD) with three replicates and compared to the least significa differences test LSD at a probability level of 0.05 . The main results are summarized : follows: The plants treated with 2.5 and $5 \mathrm{ml}^{-1}{ }^{-1}$ of Amalgerol biomarker had a significa: difference between them in each of the height of the plant, the number of leaves.plants the leaf area in addition to the dry weight of the total vegetation, while the concentration । $5 \mathrm{ml}^{-1}$ was superior in average fruit weight $(59.44 \mathrm{~g})$, fruit yield (41.95), early plant yie] $(233.52 \mathrm{~g})$, plant yield $(2.45 \mathrm{~kg})$, and early productivity $\left(3.92 \mathrm{ton} / \mathrm{ha}^{-1}\right)$, in addition total productivity of 41.15 tons.ha ${ }^{-1}$.The plants of the hybrid "Kamar" were superior average fruit weight (61.62 g) and the early plant yield $(233.40 \mathrm{~g})$ in addition to the ear productivity (3.921 tons.ha ${ }^{-1}$ ), while the hybrid plants of "Rida P1" were superior average fruit number (45.90 fruits) and the total productivity $\left(37.78\right.$ tons.ha $\left.{ }^{-1}\right)$. Tl interaction between the two factors of the stem and the average number of leaves. Plants. and the rate of the number of fruits.plants ${ }^{-1}$.
\end{abstract}

Key words: Sweet pepper, Hybrids, Amalgerol, Yield, Crop.

\section{Introduction}

Sweet Pepper Capsicum annuum L. is a herbaceous plant native to Central and South America (Thang, 2007) is the third crop in the Solanaceae family in terms of economic importance after tomatoes and potatoes (Khafaji \& Mukhtar, 1989). Pepper is grown for fruits that are eaten fresh or cooked or canned. Its importance lies in the fact that it contains the materials necessary to supply the human body with energy compounds that are important for metabolism. Each 100 grams of fresh fruits contains 4.8 grams of carbohydrates and 1.2 grams of protein as well as iron, potassium and calcium salts in addition to fluorine, which prevents tooth decay (Khalil, 2004). The total area planted 
with this crop throughout Iraq in 2012 was 33840 dunum and with a total production capacity of 922925 tons and an average of 2727 kg.dunum $^{-1}$ (Central Organization for Statistics and Information Technology, 2015).

Bio-fertilizers are fertilizers that are prepared for plants without harming health, as well as being cheap, economical and easy to prepare and use (Tisdale et al., 1997). Odell (2003) pointed out that seaweed extract contains the essential nutrients of the plant containing the major nutrients $(\mathrm{N}, \mathrm{P}, \mathrm{K})$ and the micro nutrients ( $\mathrm{Fe}, \mathrm{B}, \mathrm{Mg}, \mathrm{Zn}, \mathrm{Mo}, \mathrm{Cu}$ ), in addition to contain hormones such as Auxins, Gibberellins and Cytokinins that stimulate vegetative and root growth by increasing photosynthesis efficiency as well as protecting plants from stress.

Bio-fertilizers mostly added in small quantities as natural substances, affect many physiological processes, and increase antioxidant activity that helps the plants tolerate stress conditions, stimulates and improves growth, increase and nutritional value (Parađiković et al., 2011). The correct use of extracts can increase the strength of growth and resistance to plant diseases. Spraying it or adding it to soil improves the growth of the root mass, improves physical and chemical soil properties, their moisture retention and microbiology. (Zodape et al., 2011).

In a study of Mohammed et al. (2010), when spraying the tomato plants with a 2 ml. $\mathrm{l}^{-1}$ of Kalabac bio-stimulator, a significant increase in the number of fruits and total yield was achieved. Al-Rubaie \& Adab (2014) pointed out that spraying sweet pepper plants California Wonder variety grown in greenhouses led to a significant increase in stem diameter $(1.31 \mathrm{~cm})$, soft weight $(330 \mathrm{~g})$ and dry weight $(45.03 \mathrm{~g})$ for vegetative group compared with comparison plants. Alzubaidi
\& Alhamzawi (2015) found that spraying sweet pepper plants with $6 \mathrm{ml}^{-\mathrm{l}^{-1}}$ of seaweed extract leads to a significant increase in the number and weight per plant. Al-Tuhafi et al. (2016) observed that the effect of interaction between adding Humobacter-A fertilizer at the level of $3000 \mathrm{~kg} \cdot \mathrm{ha}^{-1}$ and spraying with paper fertilizer TOP 10 with a concentration of $3 \mathrm{~g} . \mathrm{L}^{-1}$ to Eggplant plants Jawahir variety achieved the highest rate of plant height, number of branches, number of leaves and leaf area.

Due to the great interest lately in organic bio-fertilization and considering it as one of the important methods of fertilization and reducing the excessive use of chemical fertilizers, this study aims to evaluate the efficiency of irrigation with the bio-stimulator Amalgerol in the growth and yield of pepper plants as well as finding the best variety for cultivation in desert areas.

\section{Materials \& Methods}

The field experiment was conducted during the agricultural season 2016-2017 in one of the greenhouses belonging to the Directorate of Agriculture of Basra in Khor Al-Zubair in sandy clay soil. The experiment consisted of two interactions of two varieties of sweet pepper "Kamar and Rida F1" and three concentrations of the Amalgerol bio-

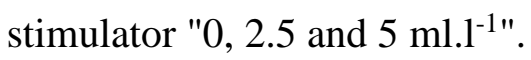

Randomized Complete Block Design (R.C.B.D) was used for a factorial experiment for with split plot design for 3 replicates. The variety was considered as the main-plot and the irrigation with Amalgerol was considered as sub-plot with three replicates to include 18 experimental units. All averages were statistically analyzed using the statistical program, Genstat 2013, and a least significant difference (L.S.D) was used to compare the averages at the probability level of 0.05 . 
The soil of the greenhouse was prepared with a deep plowing and settling. It was planned in the form of seven benches with a length of $48 \mathrm{~m}$ for a single bench and $75 \mathrm{~cm}$ between one bench and another and $40 \mathrm{~cm}$ between one plant and another. The soil was fertilized with degraded animal fertilizers (Cow waste) with an average of 8 ton.dunum ${ }^{-}$ 1. Superphosphate $\left(\mathrm{P}_{2} \mathrm{O}_{5}\right)$ was added at a level of $50 \mathrm{~kg} . d u n u m^{-1}$ (Matloob et al., 1989), and then covered with a layer of soil $15 \mathrm{~cm}$ thick. Ground irrigation was initiated by the use of sub-surface drip irrigation system T-Tape type to irrigate plants based on artesian wells. Six benches were adopted in the experiment, counting each two as a block. After the growth of seedling was completed on 1/9/2016, seedlings were planted on 15/10/2016; the Amalgerol concentrations of 0, 2.5 and $5 \mathrm{ml}^{-1}$ were prepared and added to the root total after 30 days of planting and three times irrigation with 15 days intervals.

The service operations were carried out in a symmetrical manner for all treatments, as is the practice in the production of this crop in greenhouses. The plants were sprayed with high phosphorus NPK fertilizer by 10-30-10 after four weeks of planting, and adding urea with irrigation water at a rate of 1 g.L $\mathrm{L}^{-1}$ between one week and another, and sprayed with NPK (20-20-20) fertilizer at a rate of 1 g. $\mathrm{L}^{-1}$. A preventive program has been followed to protect the greenhouse from insect and pathogenic infections.

The following measurements for five plants from each experimental unit were taken for each of the vegetative growth indicators: plant height $(\mathrm{cm})$, stem diameter $(\mathrm{mm})$, number of main branches, total number of leaves and leaf area $\left(\mathrm{dcm}^{2}\right)$ and dry weight of total vegetation ( $\mathrm{g}$ ) as well as yield indicators: fruit number, fruit weight $(\mathrm{g})$, early plant yield $(\mathrm{g})$ and plant yield $(\mathrm{kg})$, in addition to the early and total yield (ton.ha ${ }^{-1}$ ).

\section{Results \& Discussion}

Table (1) showed the superiority of the plants that were irrigated with the Amalgerol biostimulator with concentrations 2.5 and $5 \mathrm{ml}^{-1^{-}}$ 1 , with a significant difference between them in most indicators of vegetative growth compared to comparison plants of plant height, number of leaves, leaf area in addition to the dry weight of the vegetative group, while Amalgerol did not have a significant effect in both stem diameter and number of branches. The same table explained no significant difference between varieties in all vegetative growth indices.

The interaction between factors indicated a significant effect on all vegetative growth characteristics except the diameter of the stem and the number of leaves, where the plants of the variety "Kamar" treated with Almalgerol concentration of $2.5 \mathrm{ml}^{-1}{ }^{-1}$ were significantly superior in plant height, leaf area and dry weight of $51.67 \mathrm{~cm}, 41.52 \mathrm{dcm}^{2}, 45.80 \mathrm{~g}$, respectively, compared with $48.56 \mathrm{~cm}, 31.81$ $\mathrm{dcm}^{2}$ for plant height and leaf area respectively for plants of "Rida F1" variety for comparison treatment; and $35.08 \mathrm{~g}$ for the dry weight of the vegetative group resulted from "Kamar" variety plants for the same treatment, while the plants of the "Kamar" variety treated Almalgirol $5 \mathrm{ml}^{\mathrm{l}^{-1}}$ concentration were superior in number of branches. The number of branches increased by 6.33 compared to 5.22 branches of the "Rida F1" variety plants for the same treatment. 
Al-Mahdi et al. / Basrah J. Agric. Sci., 32 (Special Issue): 163-169, 2019

Table (1): Effect of irrigation with bio-stimulator Amalgerol in some vegetative growth indicators of two sweet pepper varieties.

\begin{tabular}{|c|c|c|c|c|c|c|c|}
\hline Variety & $\begin{array}{c}\text { Amalgerol } \\
\text { treatment } \\
\left(\mathrm{ml} . \mathrm{l}^{-1}\right)\end{array}$ & $\begin{array}{l}\text { Plant } \\
\text { Height } \\
(\mathrm{cm})\end{array}$ & $\begin{array}{c}\text { Stem } \\
\text { Diamete } \\
\text { r (ml) }\end{array}$ & $\begin{array}{c}\text { Main } \\
\text { Branches } \\
\text { Per plant }\end{array}$ & $\begin{array}{c}\text { Leaves } \\
\text { Per plant }\end{array}$ & $\begin{array}{l}\text { Leaf Area } \\
\qquad\left(\mathrm{dmc}^{2)}\right.\end{array}$ & $\begin{array}{c}\text { Total } \\
\text { vegetativ } \\
\text { e dry } \\
\text { weight } \\
\text { (g) }\end{array}$ \\
\hline \multirow{3}{*}{ Kamar } & 0 & 48.67 & 9.51 & 6.11 & 67.2 & 35.28 & 38.08 \\
\hline & 2.5 & 51.67 & 10.21 & 6.11 & 80.1 & 41.52 & 45.80 \\
\hline & 5 & 49.89 & 10.03 & 6.33 & 76.0 & 39.51 & 45.35 \\
\hline \multirow{3}{*}{ Rida F1 } & 0 & 48.56 & 9.12 & 5.22 & 66.9 & 31.81 & 38.56 \\
\hline & 2.5 & 49.44 & 9.75 & 6.00 & 75.4 & 32.36 & 43.19 \\
\hline & 5 & 48.67 & 9.56 & 5.44 & 74.9 & 35.88 & 43.25 \\
\hline \multicolumn{2}{|c|}{ LSD 0.05} & 2.27 & N.S & 0.66 & N.S & 5.84 & 2.84 \\
\hline \multirow{2}{*}{ Variety } & Kamar & 50.07 & 9.92 & 6.19 & 74.4 & 38.77 & 43.07 \\
\hline & Rida F1 & 48.89 & 9.47 & 5.56 & 72.4 & 33.35 & 41.67 \\
\hline \multicolumn{2}{|c|}{ LSD 0.05} & N.S & N.S & N.S & N.S & N.S & N.S \\
\hline \multirow{3}{*}{ Amalgerol } & 0 & 48.61 & 9.32 & 5.67 & 67.10 & 33.55 & 38.32 \\
\hline & 2.5 & 50.56 & 9.98 & 6.06 & 77.80 & 36.94 & 44.49 \\
\hline & 5 & 49.28 & 9.79 & 5.89 & 75.40 & 37.70 & 44.30 \\
\hline \multicolumn{2}{|c|}{ LSD 0.05} & 1.59 & N.S & N.S & 4.31 & 3.97 & 2.39 \\
\hline
\end{tabular}

The superiority of plants treated with Amalgerol in most indicators of vegetative growth may be due to its role in stimulating roots to grow and strengthen and thus increase their ability to absorb the nutrients reflected in vegetative growth, as Valarini et al. (2009), who mentioned that organic matter plays an important role in improving the soil physical, chemical and biological properties, which in turn affect their productivity, and contribute to the processing of various nutrients and increase the activity of soil biota because it is a key source of carbon necessary for metabolism. This is also explained by the superiority of plants treated by irrigation compared to untreated plants due to the provision of essential nutrients to plants that directly or indirectly affect plant biological 
Al-Mahdi et al. / Basrah J. Agric. Sci., 32 (Special Issue): 163-169, 2019

processes. These results are consistent with the findings of Ewulo et al. (2007).

It is clear from table (2) that there is a significant effect of the variety in most components of the plant yield apart from yield per plant. The "Kamar" variety plants were significantly superior in both the fruit weight and the early plant yield in addition to the early productivity of $61.62 \mathrm{~g}, 233.40 \mathrm{~g}$ and 3.921 tons respectively, while the Rida F1 variety significantly surpassed the average number of fruits and total productivity was 45.90 fruits, 37.78 tons.ha ${ }^{-1}$ respectively.

Table (2): Effect of irrigation with Amalgerol on some indicators of the yield of two sweet peppers varieties.

\begin{tabular}{|c|c|c|c|c|c|c|c|}
\hline Variety & $\begin{array}{c}\text { Amalgerol } \\
\text { Treatment } \\
\left(\mathrm{ml} . \mathrm{l}^{-1}\right)\end{array}$ & $\begin{array}{c}\text { Fruit } \\
\text { Weight } \\
\text { (g) }\end{array}$ & $\begin{array}{c}\text { Fruits } \\
\text { Per } \\
\text { plant }\end{array}$ & $\begin{array}{c}\text { Early plant } \\
\text { yield } \\
\text { (g) }\end{array}$ & $\begin{array}{l}\text { Plant } \\
\text { yield } \\
(\mathrm{kg})\end{array}$ & $\begin{array}{c}\text { Early } \\
\text { 'roductivity } \\
\left(\text { ton.ha }^{-1}\right)\end{array}$ & $\begin{array}{l}\text { Total } \\
\text { Productivity } \\
\left.\text { (ton.ha } \text { ha }^{-1}\right)\end{array}$ \\
\hline \multirow{3}{*}{ Kamar } & 0 & 55.37 & 28.90 & 212.98 & 1.597 & 3.578 & 26.84 \\
\hline & 2.5 & 64.43 & 27.97 & 216.37 & 1.800 & 3.635 & 30.24 \\
\hline & 5 & 65.05 & 35.79 & 270.84 & 2.308 & 4.550 & 38.78 \\
\hline \multirow{3}{*}{ Rida F1 } & 0 & 45.38 & 38.05 & 142.43 & 1.721 & 2.393 & 28.91 \\
\hline & 2.5 & 47.34 & 51.52 & 153.02 & 2.435 & 2.571 & 40.91 \\
\hline & 5 & 53.84 & 48.11 & 196.19 & 2.591 & 3.296 & 43.53 \\
\hline \multicolumn{2}{|c|}{ LSD 0.05} & 2.04 & N.S & 4.10 & 0.061 & 0.069 & 1.03 \\
\hline \multirow{2}{*}{ Variety } & Kamar & 61.62 & 30.89 & 233.40 & 1.902 & 3.921 & 31.95 \\
\hline & Rida F1 & 48.85 & 45.90 & 163.88 & 2.249 & 2.753 & 37.78 \\
\hline \multicolumn{2}{|c|}{ LSD 0.05} & 1.57 & 1.08 & 2.60 & N.S & 0.044 & 1.04 \\
\hline \multirow{3}{*}{ Amalgerol } & 0 & 50.38 & 33.47 & 177.71 & 1.66 & 2.99 & 27.87 \\
\hline & 2.5 & 55.89 & 39.75 & 184.69 & 2.12 & 3.10 & 35.58 \\
\hline & 5 & 59.44 & 41.95 & 233.52 & 2.45 & 3.92 & 41.15 \\
\hline \multicolumn{2}{|c|}{ LSD 0.05} & 1.67 & 1.26 & 3.44 & 0.047 & 0.058 & 0.78 \\
\hline
\end{tabular}


On the same table, the plants are treated with a $5 \mathrm{ml} . \mathrm{l}^{-1}$ concentration of Amalgerol were significantly superior in most indicators of fruit weight, number of fruits, early plant yield, plant yield and early productivity in addition to the total productivity of $59.44 \mathrm{~g}$, 41.95 fruit, $233.52 \mathrm{~g}, 2.45 \mathrm{~kg}, 3.92$ tons.ha $^{-1}$ respectively, compared to plants treated with $2.5 \mathrm{ml}^{-1}$ concentration and plants of comparison treatment.

The interaction between the two factors of the study, the plants of "Kamar" variety treated with Amalgerol at a concentration of $5 \mathrm{ml}^{-\mathrm{l}^{-1}}$ were superior in fruit weight, early plant yield and early productivity was $65.05 \mathrm{~g}, 270.84 \mathrm{~g}$ and 4.550 ton.ha ${ }^{-1}$ respectively, compared with the lowest value produced from the comparison plants for the "Rida F1" variety which was $45.38 \mathrm{~g}, 142.43 \mathrm{~g}$ and 2.393 ton.ha1 respectively, while the plants of "Rida F1" variety treated with Amalgerol at a concentration of $2.5 \mathrm{ml}^{. \mathrm{l}^{-1}}$ were superior in the total plant yield and total productivity of 2.591

\section{Conclusions}

We conclude from this study that the plants of "Kamar" variety gave the best early plant yield and early productivity, while the "Rida F1" variety plants gave the highest total productivity while the treatment of pepper plants with Amalgerol concentration of $5 \mathrm{ml}^{-}{ }^{-}$ ${ }^{1}$ gives the best indicators of yield.

\section{Acknowledgements}

Thanks and appreciation to the Directorate of Agriculture of Basrah $\backslash$ Tomato Planting Project for their cooperation and help in while carrying out the research.

\section{References}

Abdel-Mawgoud, A.M.; Tantaway, A.S; Hafez, M.M. \& Habib, H.A (2010). Seaweed extract improves growth, yield $\mathrm{kg}$ and 43.53 tons.ha ${ }^{-1}$, respectively, compared with the lowest value of $1.597 \mathrm{~g}$ and 26.84 tons.ha ${ }^{-1}$, respectively, resulted in plants compared to the variety of "Kamar".

The increase in the yield resulting from treatment with bio-stimulators may be attributed to their role in encouraging vegetative growth and increase the photosynthesis process (Table 1), thus obtaining the availability of processed food in accordance with the requirements of the fruit sets which is positively reflected in increasing the number of fruits and improving their quality Abdel-Mawgoud et al. (2010) and agreed with that Zodapa et al. (2011), or increase the vegetative growth and increase the efficiency of the process of photosynthesis has been reflected positively in the provision of food supply of flowers and increase the proportion of flower sets, which was reflected in the number of fruits as well as increase the food that reach the fruit and improve quality and quantity (Kowalczyk \& Zielony, 2008).

and quality of different watermelon hybrids. Res. J. Agric. Biol. Sci., 6(2): 161-168.

Al-Khafaji, M.A. \& Mukhtar, F.A. (1989). Production of fruits and vegetables. Ministry of Higher Education and Scientific Research. Univ. Baghdad. Bait Al-Hikma: 468pp.

Al- Rubaee, B.; Hade, CH. \& Athab, M.Z. (2014). Effect of paper fertilization and method of cultivation in the growth and yield of pepper plant California Wonder variety cultured in greenhouses. AlMuthanna J. Agric. Sci., 2(1): 17-28.

Al-Tuhafi, S.; Abdul-Majid, A.; Riyadh, G.K.; Ali, H.A. \& Lazim, M.H. (2016). Effect of adding bio-fertilizer HumobacterA and irrigation with paper fertilizer Top 
10 in the growth and yield of Eggplants of Jawahir variety. Euphrates J. Agric. Sci., 8(4): 107- 116.

Al-Zubaidi, I.A. \& Al-Hamzawi M.K (2015). Effect of spraying with sea weed extract and amino acids in some flower and fruits characteristics of sweet pepper plants Capsicum annuum L. under the conditions of greenhouses. Al-Qadisiyah J. Agric. Sci. (QJAS), 7(1): 1-13.

Central Organization for Statistics and Information Technology (2015). Secondary crops and vegetables. Directorate of Agricultural Statistics. Ministry of Planning and Development Cooperation. Republic of Iraq: 51pp.

Ewulo, B.S.; Hassan, K.O. \& Ojeniy S.O. (2007). Comparative effect of cow dung manure on soil and leaf nutrient and yield of pepper. Int. J. Agr. Res., 2(12): 10431048.

Khalil, M.A.I. (2004). Vegetables and propagation plants - nurseries - cultivation of plant cells and tissues. Division vegetation description varieties. Univ. Zagazig. Knowledge facility. Alexandria: $218 p p$.

Kowalczyk, K.A. \& Zielony, T.D. (2008). Effect of Amino plant and Asahi on yield and quality of lettuce grown on Rockwool. Conf. Biostmulatirs in modern Agriculture, 7-8 Feb. 2008, Warsaw, Poland.

Matloob, A.N.; Ezzedine, S.M. \& Karim S.A. (1989). Vegetables production, part one. Dar Al Kutb Prin. Publ.. Univ. Mosul: 680pp.

Mohammed, A.R.S.; Faisal, A. R. \& Niran, S.R. (2010). Effect of date of planting and spraying with marine extracts in the growth and yield of two varieties of tomato. Basrah J. Agric. Sci., 23(2): 4153.

Odell, C. (2003). National plant hormones are bio-stimulants helping plant. Develop higher plant antioxidant activity for multiple benefits. Extension Horticulturist Emeritus, Va. Tech, www.ext.vt.edu.

Parađiković, $\quad$ N.; $\quad$ Vinković, $\quad T$.; VinkovićVrček, I.; Źuntar, I.; Bojić, M. \&Medić-Šarić, M. (2011). Effect natural biostimulants on yield and nutritional quality: an example of sweet yellow pepper Capsicum annuum L. plant. J. Sci. Food Agric., 91: 2146-2152.

Thang, P.T.N. (2007). Ripening behavior of capsicum (Capsicum annuum L.) fruit. Ph. Thesis. Univ. Adelaide, South Australia: 149pp.

Tisdale, S.L.; Nelson W.L.; Beaton J.D. \& Havlin J.L, (1997). Soil Fertility and Fertilizer. $5^{\text {th }}$ ed. The Macmillan pub1. Co. New York: 634pp.

Valarini, P.J.; Curaqueno G.; Seguel A.; Manzano, K.; Rubio, R.; Cornejo, P. \& Borie F. (2009). Effect of compost application on some properties of a volcanic soil from central south Chili. Chilean J. Agric. Res. 69(3): 416-425.

Zodape, S.T.; Gupta, A. \& Bhandari S.C. (2011). Foliar application of seaweed sap as bio stimulant for enhancement of yield and quality of tomato (Lycopersicon esculentum Mill.). J. Sci. Ind. Res., 70: 215-219. 